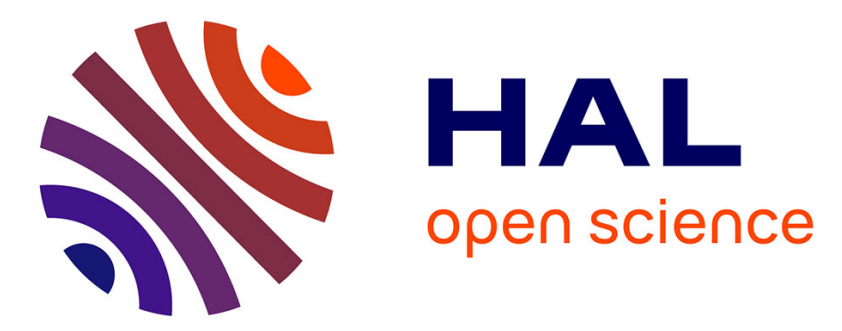

\title{
Spatial and temporal variations of glacial erosion in the Rhône valley (Swiss Alps): Insights from numerical modeling
}

Pietro Sternai, Frédéric Herman, Pierre G. Valla, Jean-Daniel Champagnac

\section{- To cite this version:}

Pietro Sternai, Frédéric Herman, Pierre G. Valla, Jean-Daniel Champagnac. Spatial and temporal variations of glacial erosion in the Rhône valley (Swiss Alps): Insights from numerical modeling. Earth and Planetary Science Letters, 2013, 368, pp.119-131. 10.1016/j.epsl.2013.02.039 . insu-00853433

\section{HAL Id: insu-00853433 \\ https://hal-insu.archives-ouvertes.fr/insu-00853433}

Submitted on 17 Dec 2013

HAL is a multi-disciplinary open access archive for the deposit and dissemination of scientific research documents, whether they are published or not. The documents may come from teaching and research institutions in France or abroad, or from public or private research centers.
L'archive ouverte pluridisciplinaire HAL, est destinée au dépôt et à la diffusion de documents scientifiques de niveau recherche, publiés ou non, émanant des établissements d'enseignement et de recherche français ou étrangers, des laboratoires publics ou privés. 


\title{
Spatial and temporal variations of glacial erosion in the Rhône valley (Swiss Alps): Insights from numerical modeling
}

- Pietro Sternai ${ }^{\mathrm{a}}$

- Frédéric Herman ${ }^{\mathrm{b}}$

- Pierre G. Valla ${ }^{a}$

- Jean-Daniel Champagnac ${ }^{\mathrm{a}}$

- $\quad{ }^{a}$ Geological Institute, Swiss Federal Institute of Technology (ETH), Zürich, Switzerland

- $\quad{ }^{\mathrm{b}}$ Institute of Earth Sciences, University of Lausanne, Switzerland

Corresponding author. Now at: the Institut de Science de la Terre d'Orléans (ISTO), University of Orléans, France. Tel.: +33631910242.

\begin{abstract}
The present-day topography of the European Alps shows evidence of intense glacial reshaping. However, significant questions regarding Alpine landscape evolution during glaciations still persist. In this study, we focus on the Rhône valley (Swiss Alps), and use a numerical model to estimate patterns and magnitudes of glacial erosion. Comparing modeling results on a reconstructed pre-glacial topography and the present-day landforms, we find that the landscape response to glaciation is more complex than a simple "buzzsaw" mechanism (by which glacial erosion sets the height of mountain ranges) or increase of relief due to localized valley incision. Instead, glacial erosion propagates headward as the landforms evolve from a fluvial to a glacial state, leading to an initial increase of local relief followed by subsequent erosion at high elevations. It has also been proposed that the mid-Pleistocene climatic transition of glacial/interglacial oscillations from periods of $40 \mathrm{kyr}$ (with symmetric shapes) to periods of $100 \mathrm{kyr}$ (with asymmetric shapes) promoted glacial erosion within the Alps. Although this change of climate periodicity may have contributed to enhance glacial erosion, our results suggest that other factors such as an increase in rock uplift and/or progressive climate cooling are required to explain enhanced glacial carving at $\sim 1 \mathrm{Ma}$.
\end{abstract}

\section{Keywords}

- glacial erosion;

- numerical modeling;

- topographic relief;

- sediment yield

\section{Introduction}

Pleistocene glaciations have played a fundamental role in the evolution of high-elevation and mid- to high-latitude mountain ranges on Earth (e.g., Penck, 1905 and Sugden and John, 1976). Glacial processes affect landscape evolution (e.g., Montgomery, 2002, Brocklehurst 
and Whipple, 2002 and Koppes and Montgomery, 2009) and produce conspicuous morphologies such as "U"-shaped valley, steep-sided and hanging valleys (e.g., Harbor et al., 1988, Anderson et al., 2006 and Valla et al., 2010) as well as over-deepened valleys (e.g., Preusser et al., 2010). However, significant questions about the overall effects of glacial erosion on the topographic evolution of a mountain range still remain. Large scale topographic analyses suggest that glacial erosion is maximized at and above the glaciers' long-term Equilibrium Line Altitude (ELA) (e.g., Broecker and Denton, 1989, Brozovic et al., 1997, Brocklehurst and Whipple, 2002 and Egholm et al., 2009), the amount of rock above this limit being set by the rock strength (Schmidt and Montgomery, 1996). This mechanism is commonly referred to as glacial "buzzsaw" (e.g., Spotila et al., 2004). In contrast, measurements of long-term denudation rates from low temperature thermochronology suggest high erosion towards low altitudes, which in turn leads to an increase of local relief in response to glacial erosion (e.g., Shuster et al., 2005, Ehlers et al., 2006 and Valla et al., 2011). Recent studies based on numerical modeling (Herman et al., 2011), sediment budget analysis (Steer et-al., 2012 and Philippe et al., 2012) and global topographic compilations (Champagnac et al., 2012) proposed a reconciled view of these apparently contrasting mechanisms by showing that combined glacial processes actually produce significant topographic modifications both around the ELA and towards lower reaches. Nonetheless, the temporal and spatial evolution of glacial erosion as the landforms evolve from a fluvial to a glacial state is elusive.

Glacial processes also play an important role in the complex feedbacks between tectonics, climate and erosion (e.g., Roe et al., 2008). Late Cenozoic global cooling (Zachos et al., 2001) seems to have led to a global increase in sediment yield (e.g., Zhang et al., 2001 and Hay et al., 2002) and produced additional components of rock uplift (e.g., Molnar and England, 1990 and Mitrovica and Peltier, 1991). Although some have recently questioned these effects (e.g., Willenbring and von Blanckenburg, 2010), it has been shown that glacial processes triggered major changes in sediment fluxes (e.g., Piper et al., 1994 and Bowerman and Clark, 2011) and modern patterns of rock uplift (e.g., Pelletier, 2004 and Spotila et al., 2004).

These effects are observed in the European Alps which, given the historical and geological record of past glaciations, are often used as a natural laboratory to investigate how glacial processes affected the topographic evolution of orogenic belts (e.g., Molnar, 2004,

Champagnac et al., 2007 and Norton et al., 2010). Recent studies suggest an increase of the valley scale relief in response to local glacial erosion (Häuselmann et al., 2007b, Glotzbach et al., 2011 and Valla et al., 2011), which contrasts with a strong glacial imprint at the mean long-term ELA (Sternai et al., 2011) and prominent glacial cirques at even higher elevations (Anders et al., 2010). Furthermore, measurements of sediment yields from the western Alps are consistent with a global increase since $\sim 5 \mathrm{Ma}$ (Hay et al., 1992, Kuhlemann, 2000, Zhang et al., 2001 and Kuhlemann et al., 2001), but clearly predate glacially enhanced valley carving (Häuselmann et al., 2007a and Valla et al., 2011) and first glacial deposits to the Po foreland basin (Muttoni et al., 2003) at $\sim 1 \mathrm{Ma}$. The onset of intense glacial erosion within the Alps thus seems to correlate with the mid-Pleistocene climatic transition from $40 \mathrm{kyr} / \mathrm{symmetric}$ to $100 \mathrm{kyr} /$ asymmetric glacial/interglacial oscillations (e.g., Broecker and van Donk, 1970, Fairbridge, 1972 and Lisiecki and Raymo, 2007), but further work is needed to validate this hypothesis.

In recent years, numerical modeling has been used to investigate processes of glacial erosion (e.g., Harbor et al., 1988, Tomkin and Braun, 2002, Amundson and Iverson, 2006, Herman and Braun, 2008 and Herman et al., 2011). A common result is that hypsometry (i.e., the 
distribution of elevations) has a significant effect on ice extent as well as the patterns and magnitudes of glacial erosion (Braun et al., 1998, Egholm et al., 2009 and Sternai et al., 2011). However, the morphology of a landscape before the onset of glaciations is rarely known and most previous studies were based on either present-day or synthetic "fluvial" topographies. Recently, Sternai et al. (2012) proposed a new method to reconstruct a preglacial topography and applied it to the European Alps. This work provides us with the unique opportunity to evaluate the efficiency of glacial erosion on such a pre-glacial landscape. By comparing patterns and magnitudes of glacial erosion on the pre-glacial topography to those obtained on the present-day landscape, we can address the spatial and temporal evolution of glacial erosion in the European Alps, as well as the potential tectonic/climatic forcing on glacial processes and sediment production.

This study focuses on the Rhône valley (Switzerland), one of the major drainage systems of the European Alps (Fig. 1). In the following, we first describe the observations we use to constrain our landscape evolution model. We then outline the modeling strategy, provide an overview of the numerical model and report the numerical experiments. Finally, we present and discuss the model results. We show that glacial erosion is more complex than a simple "buzzsaw" effect (Brozovic et al., 1997, Mitchell and Montgomery, 2006 and Egholm et al., 2009) or increase of topographic relief (e.g., Häuselmann et al., 2007b, Glotzbach et al., 2011, Valla et al., 2011 and Ward et al., 2012). Instead, glacial erosion propagates headward through time, with consequent initial increase of topographic relief and subsequent erosion at higher elevations along the valleys. The change of climate periodicity corresponding to the mid-Pleistocene transition, finally, may have produced an intensification of glacial erosion. However, our results suggest that additional factors such as an increase of rock uplift and/or progressive climate cooling are required to explain enhanced glacial carving at $\sim 1 \mathrm{Ma}$. 


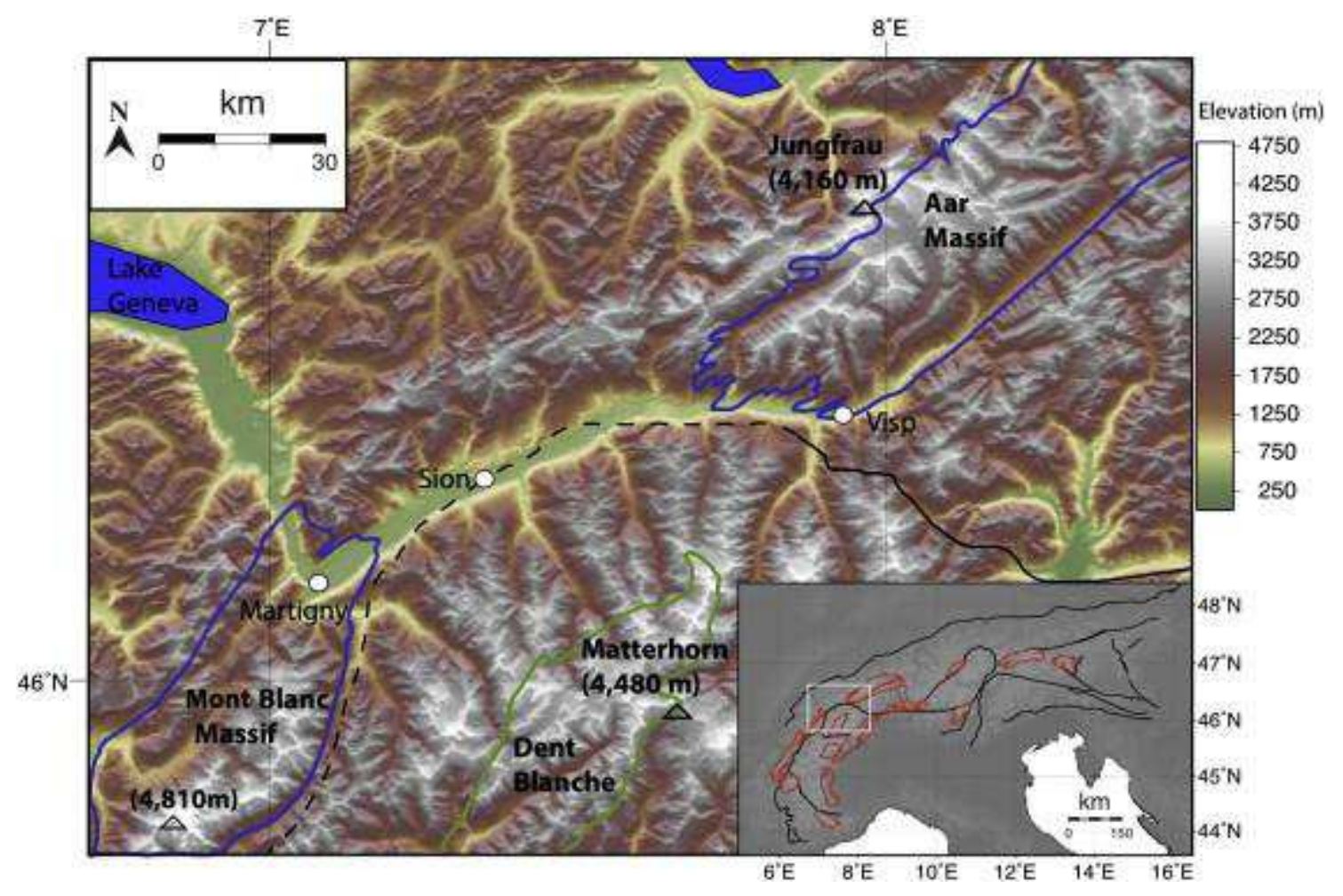

Fig. 1. : Topography of the Rhône catchment. Major tectonic lineaments (the Rhône-Simplon fault zone, e.g., Mancktelow, 1985) are represented with black (solid or dotted) line. The south-eastern side of the area is mainly composed by Penninic units while the north-western side is mostly occupied by Helvetic nappes. Blue and green lines represent the External Crystalline Massifs (Mont Blanc and western Aar) and the Dent-Blanche zone (Austro Alpine), respectively (Schmid et al., 2004). Inset shows the location of the study area within the European Alps, as well as major tectonic lineaments (black lines) and units (red lines). See, for example, Schmid et al. (2004) for more detail.

\section{Setting一the Rhône valley}

In this section, we outline the major geologic, geomorphic and geodetic observations that have directed our study. We only emphasize aspects that are most appropriate for this analysis, while we refer the reader to other articles for further details about the geological setting (e.g., Steck and Hunziker, 1994 and Schmid et al., 2004), the seismotectonics and neotectonics (e.g., Maurer et al., 1997, Champagnac et al., 2003 and Schlatter et al., 2005) and the glacial history (e.g., Ivy-Ochs et al., 2006).

\subsection{Geomorphology and glacial record}

The Rhône valley (Fig. 1) is one of the major drainage systems of the European Alps ( $\sim 6000 \mathrm{~km}^{2}$ drainage area). While the principal geological and structural elements of the Rhône valley were already established by the end of the Oligocene (e.g., Schmid et al., 2004), Pleistocene glaciations and associated isostatic adjustment heavily impacted the valley (e.g., Kelly et al., 2004). Glacial erosion contributed in generating a high relief landscape with peaks over $4000 \mathrm{~m}$ and several over-deepenings up to $1000 \mathrm{~m}$ deep (Jaboyedoff and Derron, 2005 and Preusser et al., 2010). Glacial erosional features such as trimlines, striae or polished 
rocks are abundant. The valley bottom mostly preserves a conventional "U"-shape. While little information about most of the classical Alpine fourfold glaciation system (i.e., Günz, Mindel, Riss and Würm glaciations, e.g., Penck and Brückner, 1909 and Buoncristiani and Campy, 2004) is preserved within the study region, prominent moraine systems and associated deposits belonging to the post Last Glacial Maximum (LGM, at $\sim 20 \mathrm{kyr}$, Ivy-Ochs et al., 2006) and late-Holocene deglaciation provide an important morphological reference along the Rhône valley (e.g., Kelly et al., 2004). Reconstructions of LGM ice extent show that the Rhône valley was covered by up to 1500 mof ice (Florineth and Schlüchter, 1998 and Kelly et al., 2004). Although such glacial reconstructions and their relations with past climate are relatively well established, the physical processes controlling ice building and glacial erosion patterns are still elusive.

Sternai et al. (2012) recently proposed a reconstruction of the pre-glacial landscape of the European Alps, which accounts for spatially variable channel steepness and isostatic adjustment to Pleistocene erosion. By comparing the pre-glacial landscape to the present-day topography over the whole European Alps, it was possible to constrain patterns and integrated magnitudes of glacial erosion. The results suggest an increase in valley-scale relief, in spite of a decrease in orogen-scale mean elevation (Sternai et al., 2012). This landscape modification is also verified in the Rhône valley, where the hypsometries before and after glaciation show the development of high peaks, the lowering of the valley bottom and the formation of overdeepened troughs (Fig. 2).

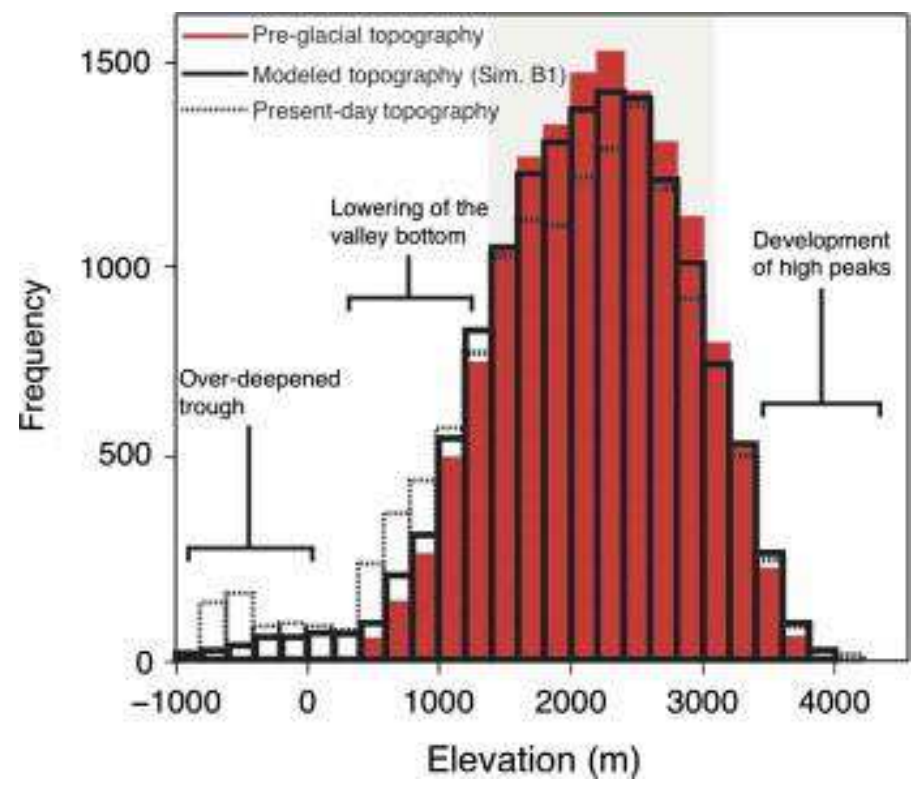

Fig. 2. : Hypsometry of the Rhône catchment. Red bars represent the hypsometry of the Rhône valley prior Pleistocene glaciation (Sternai et al., 2012). Black bars show the hypsometry of the Rhône valley at the end of numerical experiment B1 (see Table 1 and text for details). Dotted black bars represent the present-day hypsometry of the Rhône valley corrected for the sediment cover (based on estimates of post glacial sediment infill by Jaboyedoff and Derron, 2005). The gray envelope represents LGM and modern ELAs as estimated by Ivy-Ochs et al. (2006) or compiled by the World Glaciers Monitoring Service (IUGG/UNEP/UNESCO, 2005) 


\subsection{Tectonic/isostatic rock uplift}

Rock uplift modulated by erosion may enhance the accumulation area of glaciers in turn affecting ice thickness, glacial erosion and sediment yield (e.g., Herman and Braun, 2008, Kaplan et al., 2009 and Yanites and Ehlers, 2012). Variations in rock uplift and exhumation rates have occurred during the late Neogene and Pleistocene (e.g., Vernon et al., 2008 and Sternai et al., 2012). However, the magnitude and timing of these changes are not sufficiently well resolved to provide information about the evolution of rock uplift patterns throughout Pleistocene glaciations. GPS data indicate that negligible horizontal motion with respect to stable Europe is currently accommodated in the western Alps (Calais et al., 2002). Ongoing motion denotes East-West extension in the upper crust of the western Alps, also recognized by seismological data (e.g., Sue et al., 1999). Active tectonics thus seem to be dominated by isostasy/buoyancy forces rather then shortening along the Alpine Europe/Adria collision zone (e.g., Selverstone, 2005 and Sue et al., 2007, and references therein). Vertical displacements relative to a reference point in Aarburg (Swiss Molasse basin) are $\sim 0.25-1.5 \mathrm{~mm} \mathrm{yr}^{-1}$ (Schaer and Jeanrichard, 1974 and Schlatter et al., 2005), in response to the isostatic re-adjustment to erosion (e.g., Champagnac et al., 2007), post-LGM and ongoing ice melting (Stocchi et al., 2005 and Barletta et al., 2006), with a possible minor effect of tectonic shortening and/or deep-seated processes such as the detachment of the European slab (Calais et al., 2002 and Lippitsch et al., 2003). The relative importance of these three components in determining measured rock uplift rates, however, is still debated (e.g., Champagnac et al., 2009).

\section{Glacial erosion modeling}

In this section, we first provide a brief overview of the numerical model and then report its calibration for studying the Rhône valley. It is not our purpose to reproduce the full evolution of the Rhône valley from pre-glacial times to modern days, nor to thoroughly explain its present-day geomorphology, but rather to assess major glacially induced modifications of the topography. For these reasons, fluvial and hillslope processes as well as the effects of loose sediments on bedrock erosion or variations of rock erodibility across the study area were not treated.

\subsection{Numerical model}

We used a modified version of ICE-CASCADE (Braun et al., 1998). We provide here a brief overview of the governing equations, while more details about the algorithm and model parameters can be found in Braun et al. (1998), Tomkin and Braun (2002), Herman and Braun (2008), and Herman et al. (2011).

\subsubsection{Ice dynamics}

The ice thickness, $h$, is calculated by solving the equation of ice mass conservation equation(1)

$$
\frac{\partial h}{\partial t}=\nabla \cdot Q+M
$$


where $t$ is the time, $Q$ is the ice flux and $M$ is the ice net mass balance. $M$ is calculated as a linear function of the temperature, $T_{s}$, which scales linearly with elevation:

equation(2)

$M=-\gamma T_{s} \quad$ with $\quad T_{s}=T_{0}-\lambda(h+z)$

where $\gamma$ and $\lambda$ are arbitrary constants, $z$ is the elevation and $T_{0}$ is the temperature at sea level that varies through time to simulate glacial/interglacial cycles. Minimum $\left(M_{\min }\right)$ and maximum $\left(M_{\max }\right)$ rates of ice accumulation and ablation can also be set to reproduce a realistic ice net mass balance. To describe ice sliding velocities, $u_{s}$, we apply a commonly used empirical law ( Bindschadler, 1983, van der Veen, 1987 and Paterson, 1994)

equation(3)

$u_{5}=\frac{B_{5}}{p_{e}} \tau_{b}^{3}$

where $\tau_{b}$ is the ice basal shear stress, $B_{s}$ is a sliding constant and $p_{e}$ is the effective pressure (i.e., $p_{i}-p_{w}$, where $p_{i}$ is the ice overburden pressure and $p_{w}$ is the water pressure).

\subsubsection{Subglacial hydrology}

Following Flowers and Clark (2002), the water thickness, $h_{w}$, is computed as equation(4)

$\frac{\partial h_{w}}{\partial t}=\dot{b}+\dot{b}_{b}-\nabla \cdot Q_{w}$

where $Q_{w}$ is the water discharge, $\dot{b}=|\min (M, 0)|$ is the meltwater produced by ablation and $b_{b}$ is a background basal melt. The computation of the water pressure is based on an empirical formula

equation(5)

$p_{w}=p_{i}\left(\frac{h_{w}}{h_{c}}\right)^{3.5}$

where $h_{c}$ is the critical thickness of the confined aquifer.

\subsubsection{Glacial erosion}

Landscape evolution models often assume that glacial erosion is dominated by abrasion and quarrying (e.g., Hallet, 1979, Hallet, 1996, MacGregor et al., 2000, Anderson et al., 2006, Herman and Braun, 2008, Egholm et al., 2009 and Pelletier et al., 2010) and that these two processes are a function of the sliding velocity. A similar approximation is adopted here 
equation(6)

$\frac{\partial z}{\partial t}=k_{\mathrm{g}} u_{s}^{t}$

where $k_{g}$ is a constant and $l$ is equal to 1 .

\subsection{Model calibration}

\subsubsection{Glacial/interglacial cycle and ice net mass balance}

A shift of the period of climate oscillations from $\sim 40 \mathrm{kyr}$ to $\sim 100 \mathrm{kyr}$ is recorded at the midPleistocene transition (e.g., Broecker and van Donk, 1970, Fairbridge, 1972 and Lisiecki and Raymo, 2007). While $40 \mathrm{kyr}$ oscillations are mostly symmetric, those with a period of $100 \mathrm{kyr}$ exhibit a sawtooth shape in which abrupt reversals of the climatic trend separate longer cooling phases from shorter warming periods (e.g., Broecker and van Donk, 1970 and Fairbridge, 1972). We thus approximate the $40 \mathrm{kyr}$ cycles by varying sea level temperatures ( $T_{0}$, Eq. (2)) as a sinusoidal function and the $100 \mathrm{kyr}$ cycles by imposing a cooling period of $80 \mathrm{kyr}$ followed by $20 \mathrm{kyr}$ of climate warming.

Maximum and minimum $T_{0}$ are set equal to $18{ }^{\circ} \mathrm{Cand} 9{ }^{\circ} \mathrm{C}$, to match modern high-resolution observations of sea surface temperatures around Europe (Reynolds and Smith, 1995) as well as modern and LGM ELA estimates (i.e., $2900 \pm 150 \mathrm{~m}(1 \sigma)$ and $1700 \pm 200 \mathrm{~m}(1 \sigma)$, respectively, as detailed in IUGG/UNEP/UNESCO, 2005).

Assuming that Alpine glaciers were fed predominantly by snowfall, with a clean ablation area, we set $M_{\max }, M_{\min }, \gamma$ and $\lambda$ (Eqs. (1) and (2)) equal to $1 \mathrm{~m} \mathrm{yr}^{-1},-20 \mathrm{~m} \mathrm{yr}^{-1}, 2 \mathrm{~m}^{\circ} \mathrm{C}^{-1}$ and $0.006{ }^{\circ} \mathrm{C} \mathrm{m}^{-1}$ (Benn and Lehmkuhl, 2000), respectively.

Using this parameter setting, we could reproduce independent reconstructions of LGM ice extent by Kelly et al. (2004) and Schlüchter et al. (2009).

\subsubsection{Erosional efficiency}

The over-deepened troughs surrounding the European Alps are amongst the most prominent erosional features of the orogen (Preusser et al., 2010). Although the processes responsible for the formation of such noticeable depressions are still debated (e.g., Oerlemans, 1984, MacGregor et al., 2000, Kessler et al., 2008 and Herman et al., 2011), it is widely accepted that Alpine over-deepenings have glacial origins (e.g., Penck, 1905, Jaboyedoff and Derron, 2005 and Preusser et al., 2010). The maximum depth of the over-deepened trough within the Rhône valley has been estimated by Jaboyedoff and Derron (2005) to be 1000 mbelow the present-day topography. We reproduced over-deepened troughs of similar depths by assuming $B_{s}$ (Eq. (3)) equal to $5 \times 10^{-15} \mathrm{~Pa}^{-3} \mathrm{a}^{-1} \mathrm{~m}^{-2}$ and $k_{g}$ (Eq. (6)) equal to $2 \times 10^{-5}$ for numerical experiments over $1 \mathrm{Myr}$ and $1 \times 10^{-5}$ for numerical experiments over $2 \mathrm{Myr}$ (see Section 4).

\subsubsection{Tectonic and isostatic rock uplift}

As discussed in Section 2.2, modern rock uplift may combine different components associated with isostatic adjustment to Pleistocene erosion and recent ice melting, as well as components 
due to ongoing tectonic and/or deep-seated processes. In the following, we will refer to the passive response to Pleistocene erosion and recent ice melting as the "isostatic rock uplift". Instead, the expression "tectonic rock uplift" will be used for extra components of rock uplift due to ongoing tectonic shortening and/or mantle-related processes. We use this terminology for the sake of simplicity and ease of reading, although we are aware that these definitions are not rigorous.

We assessed the isostatic rock uplift using a two-dimensional flexural model that computes the vertical deflection of an elastic plate produced by removal of the eroded material and changes in ice load through time. We used spatially uniform crust and mantle densities (2.8 and 3.3, respectively) and set Poisson's ratio and the elastic thickness of the crust equal to 0.2 and $20 \mathrm{~km}$ (Christensen, 1996 and Stewart and Watts, 1997). The isostatic rock uplift accounts for at least $\sim 50 \%$ of the observed rock uplift (i.e., $\sim 0.25-1.5 \mathrm{~mm} \mathrm{yr}^{-1}$ Schaer and Jeanrichard, 1974 and Schlatter et al., 2005), depending on simulation settings. We thus run experiments with tectonic rock uplift rates equal to either 0 or $0.5 \mathrm{~mm} \mathrm{yr}^{-1}$ (constant in both space and time) to adjust modeled rock uplift rates to observations.

\section{Results}

We performed three numerical experiments (A, B and C), each consisting of two simulations (as summarized in Table 1). In the numerical experiment $\mathrm{A}$ we run a single glacial cycle on both the pre-glacial and present-day topography to investigate the role of the initial morphology in controlling ice dynamics as well as patterns/magnitudes of glacial erosion. In the numerical experiment $\mathrm{B}$, we explore how the landscape evolves from a fluvial to a glacial state by modeling several glacial cycles on the pre-glacial topography. In this experiment we also vary the tectonic rock uplift rates to estimate the influence of extra components of uplift. Finally, in the numerical experiment $\mathrm{C}$, we investigate the effects of a shift in the period of climate oscillations at the mid-Pleistocene transition on glacial erosion and the sediment yield. We also address the effects of rock uplift as in the experiment B. 
Table 1.

Summary of the numerical experiments and simulations. $t$ (kyr) is the simulated time, $P(\mathrm{kyr})$ is the period of climate oscillations, $r_{u}\left(\mathrm{~mm} \mathrm{yr}^{-1}\right)$ is the imposed tectonic rock uplift rate and $k_{g}$ is the glacial erosion scaling coefficient. The DEM resolution of both the present-day and pre-glacial topography is $\sim 540-780 \mathrm{~m}$ in the longitudinal and latitudinal directions, respectively. See text for more detail.

\begin{tabular}{|c|c|c|c|c|c|}
\hline \multicolumn{2}{|c|}{ Numerical experiment Sim. $n$. } & \multicolumn{4}{|c|}{$($ kyr $)($ kyr $)\left(\right.$ glac.-interglac.) $\left(\mathrm{mm} \mathrm{yr}^{-1}\right)$} \\
\hline \multirow[t]{2}{*}{$\mathbf{A}$} & A1 & 100 & $100_{(80-20)}$ & 0.5 & $2 \mathrm{e}-5$ Pre-glacial \\
\hline & $\mathrm{A} 2$ & 100 & $100_{(80-20)}$ & 0.5 & $2 \mathrm{e}-5$ Present-day \\
\hline \multirow[t]{2}{*}{$\mathbf{B}$} & B1 & 900 & $100_{(80-20)}$ & 0 & $2 \mathrm{e}-5$ Pre-glacial \\
\hline & B2 & 900 & $100_{(80-20)}$ & 0.5 & 2e-5 Pre-glacial \\
\hline \multirow[t]{2}{*}{ C } & $\mathrm{C} 1$ & 2000 & $40_{(20-20)}-100_{(80-20)}$ & 0 & 1e-5 Pre-glacial \\
\hline & $\mathrm{C} 2$ & 200 & $40_{(20-20)}-100_{(80-20)}$ & 0.5 & 1e-5 Pre-glacial \\
\hline
\end{tabular}

In order to quantitatively report the patterns and magnitudes of glacial erosion, we calculate the catchment-scale sediment yield through time and produce erosion maps of specific time steps. In addition, we selected several topographic control points along the major valley trunk and tributary valleys and track the temporal evolution of glacial erosion at these key locations.

\subsection{Numerical experiment $A$}

In this numerical experiment, we simulate one asymmetric glacial/interglacial cycle (100 kyr) on both the pre-glacial (simulation A1) and present-day (simulation A2) topography. As discussed above (Section 2.1), landscape hypsometries are different, with a higher frequency of elevations around the mean long-term ELA in the pre-glacial topography (Fig. 2).

Therefore, the ice accumulation area is larger on the pre-glacial landscape than on the presentday topography, resulting in larger ice volumes by approximately a factor of 2 during the cooling and warming phases of the glacial/interglacial cycle (Fig. 3). At the glacial maximum, however, the ice volume and extent on both topographies are similar. 

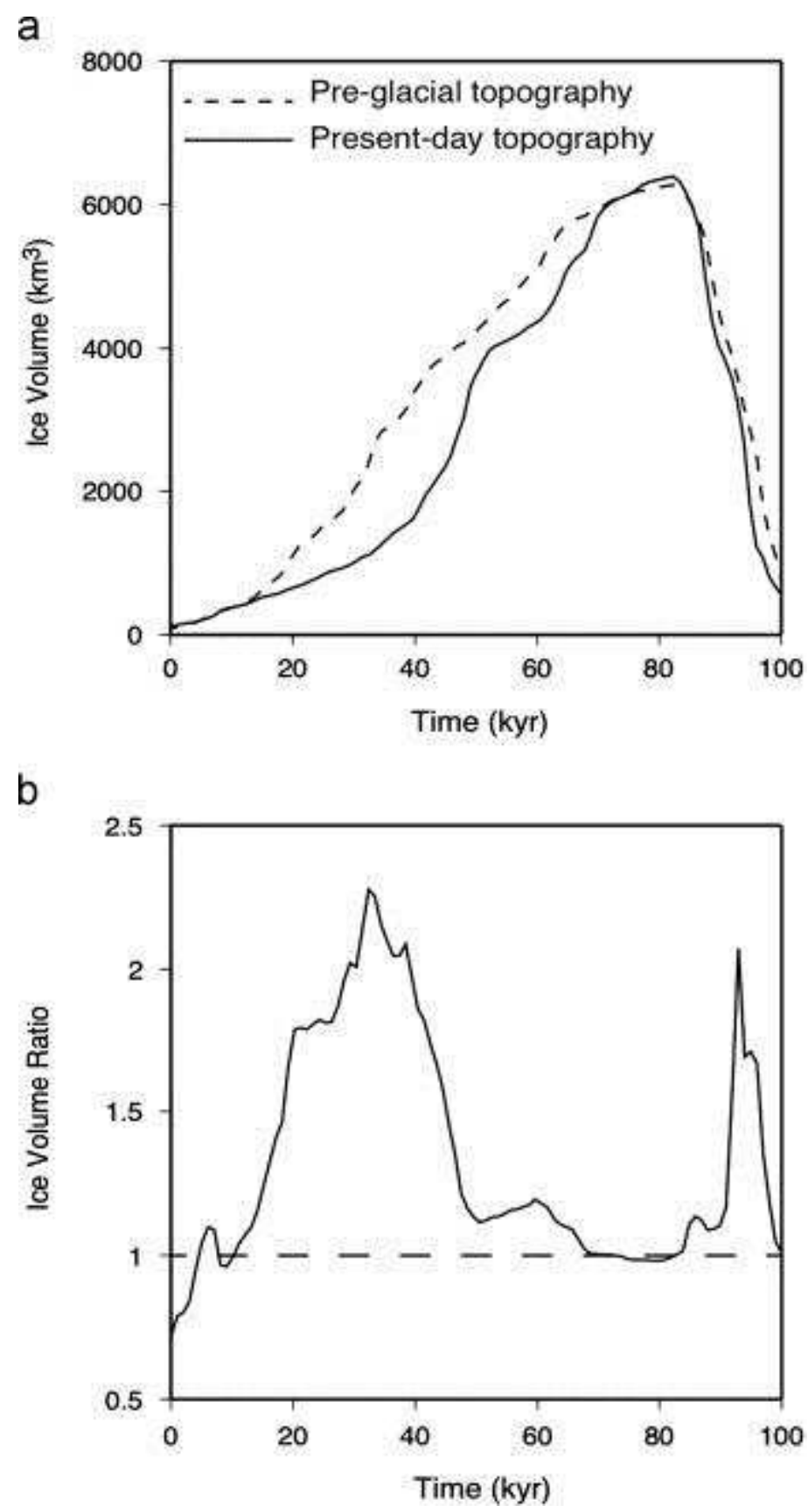

Fig. 3. : (a) Dashed and solid lines show the evolution of the ice volume through time on the pre-glacial and present-day topography, respectively (simulations A1 and A2, see text for details). (b) Ratio between pre-glacial and present-day ice volumes. The modeled ice volume on the pre-glacial topography surpass that of the present-day landscape by a factor of $\sim 2$ during both the cooling and warming phases of the glacial/interglacial cycle.

During the initial cooling, glaciers on the present-day topography are restricted to the upper parts of the catchments where they concentrate erosion (Fig. 4). In contrast, the ice cap on the pre-glacial topography develops rapidly, filling and eroding the major valley trunk. This is further illustrated by the evolution of glacial erosion at the control points (Fig. 5). Dashed lines (representing tributary lateral valleys) reveal that glacial erosion is more effective in the upper catchments of the present-day topography, indicating that magnitudes and patterns of 
glacial erosion depend on the hypsometry of the landscape. Furthermore, the present-day landscape is characterized by particularly high slopes above the ELA which increases ice sliding velocity and thus enhances glacial erosion in the high reaches of the landscape.

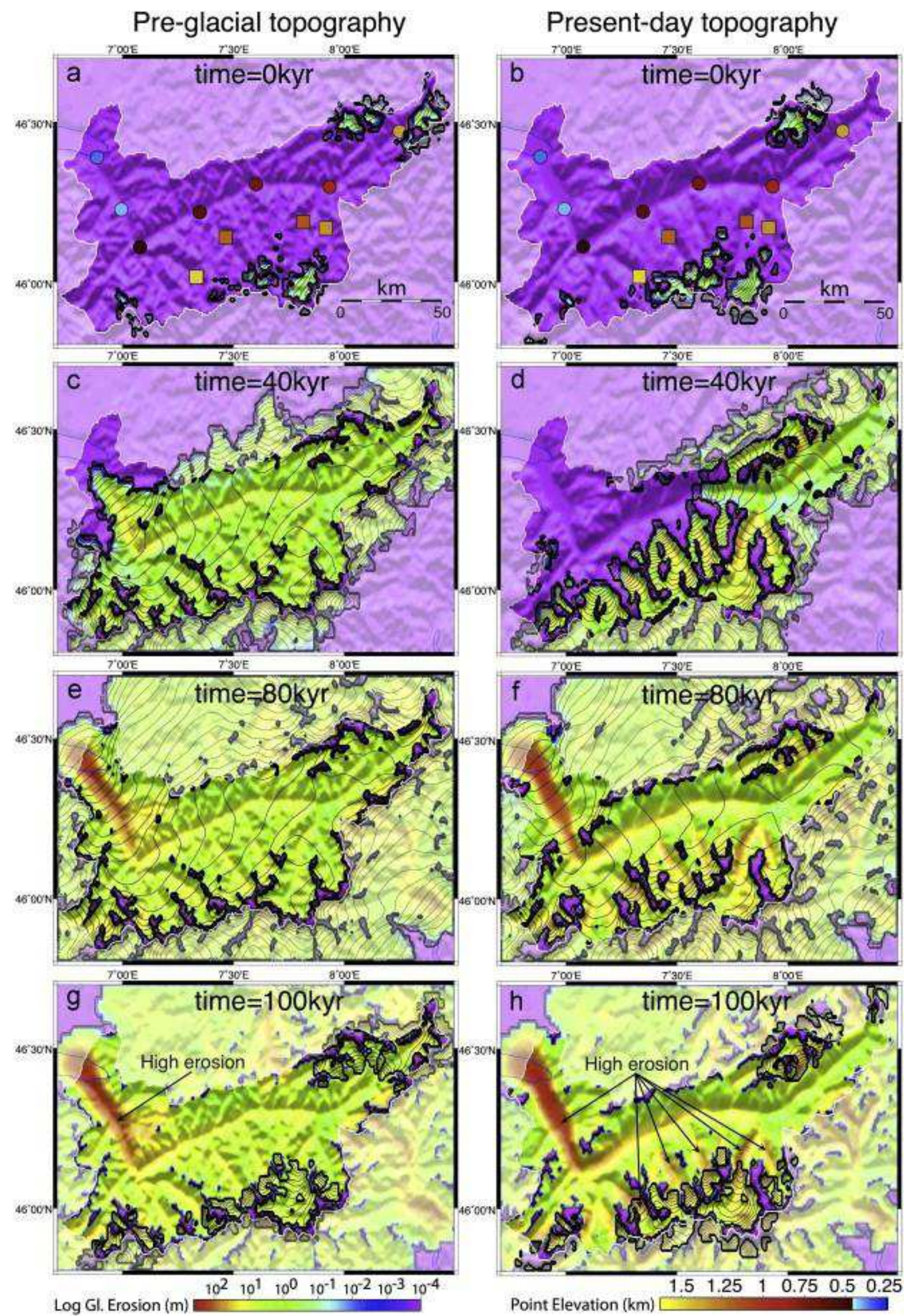


Fig. 4. : Selected snapshots of the simulations A1 and A2 (see Table 1), showing both the ice extent (black lines) and the cumulative glacial erosion (color code, see legend). The location of the control points (color-coded by elevation) is also shown in (a) and (b). See text for further details.
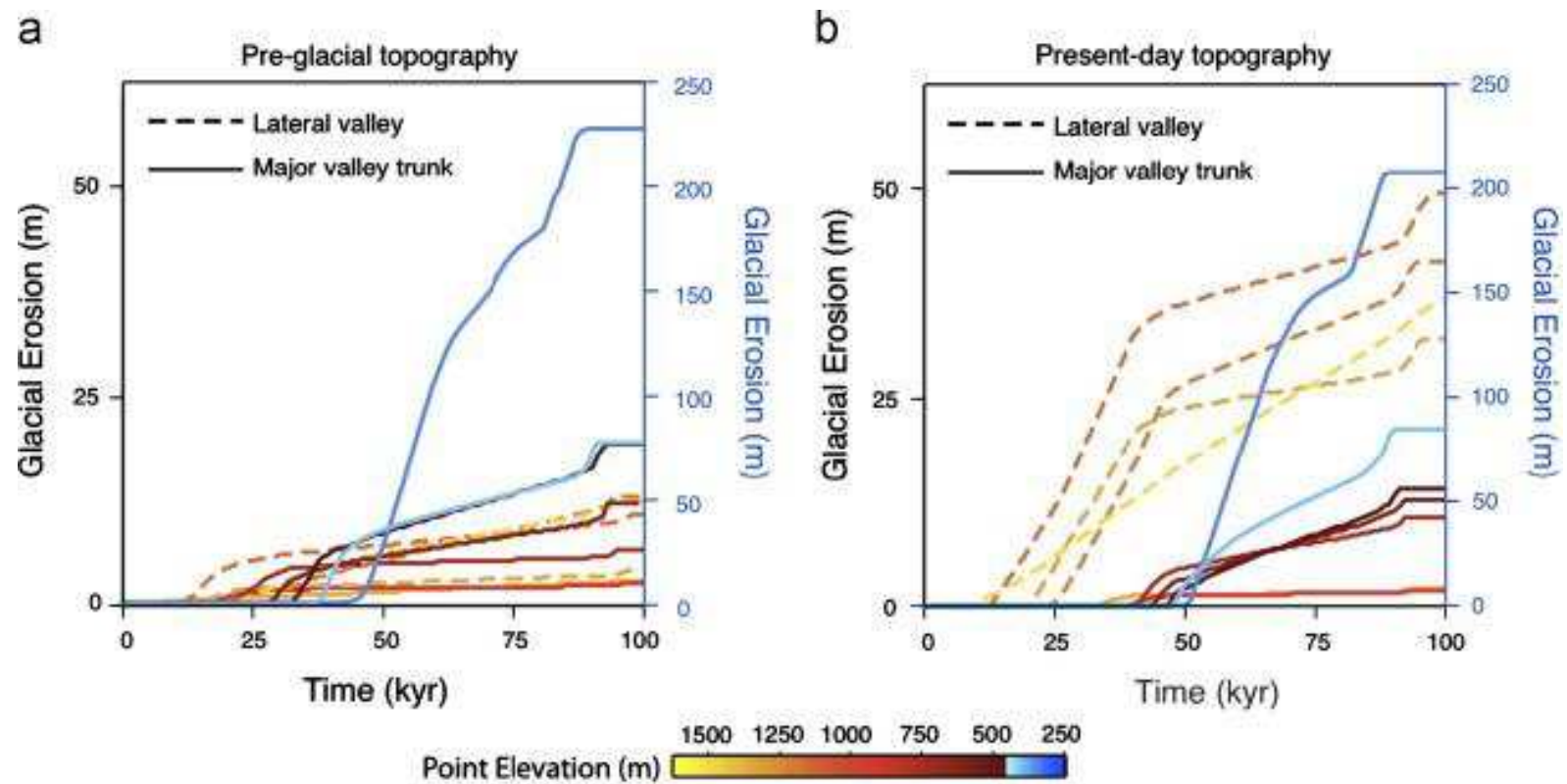

Fig. 5. : Glacial erosion through time for each control point (see Fig. 4a and b for control point locations) on the (a) pre-glacial and (b) present-day topography (simulations A1 and A2, respectively). Lines are color-coded by control point elevations. Solid and dashed lines on both panels represent glacial erosion evolution for points in the main valley trunk and lateral valleys, respectively. Glacial erosion at low elevation (light and dark blue lines on both panels) is approximately one order of magnitude higher (see scale on the right). Glacial erosion of the main valley trunk (full lines on both panels) is inversely proportional to elevation. Glacial erosion of present-day lateral valleys (dashed lines in (b)) is significantly higher than what is found on equivalent valleys of the pre-glacial landscape (dashed lines in (a)).

At the glacial maximum, subglacial water due to melting abounds in the ablation area (Herman et al., 2011), which results in a substantial increase of the sliding velocities (and thus erosion rates) at lower elevations (Fig. 4e and f). Glacial erosion of the lower parts of the landscape is approximately one order of magnitude higher than at high elevations on both topographies (Fig. 5).

Similar to the early stages of the glacial/interglacial cycle, the upper parts of the present-day topography are subject to higher glacial erosion when glaciers retreat and their size is reduced. Over a full glacial/interglacial cycle, glacial reshaping of the pre-glacial topography occurs almost exclusively in the lower reaches of the landscape (Fig. 4g), while a bimodal distribution of glacial erosion with a peak at high elevation and enhanced erosion at low altitudes occurs on the present-day topography (Fig. 4h). 


\subsection{Numerical experiment $B$}

In this numerical experiment, we address the evolution of glacial erosion patterns since the mid-Pleistocene transition (e.g., Lisiecki and Raymo, 2007). We thus simulate nine asymmetric glacial/interglacial cycles $(100 \mathrm{kyr})$ on the pre-glacial landscape, imposing tectonic rock uplift rates equal to 0 and $0.5 \mathrm{~mm} \mathrm{yr}^{-1}$ (simulations B1 and B2, respectively). The evolution of glacial erosion over several glacial/interglacial cycles is characterized by a headward propagation through time, independent of the selected tectonic rock uplift rate (Fig. $6 a$ and $b)$. This erosional headward propagation is also illustrated by the cumulative erosion and instantaneous erosion rates of each topographic control point (Fig. 7). The initial valley carving at low elevations steepens the local down-valley bedrock slopes with a resultant increase of the ice sliding velocity during subsequent glacial/interglacial cycles. This mechanism triggers headward propagation of erosion during several glacial/interglacial cycles while glacial erosion at low elevations is reduced as the steepened front moves toward the upper valley. After 0.9 Myr of glacial erosion, an over-deepened trough comparable to the one observed today is formed. 
a

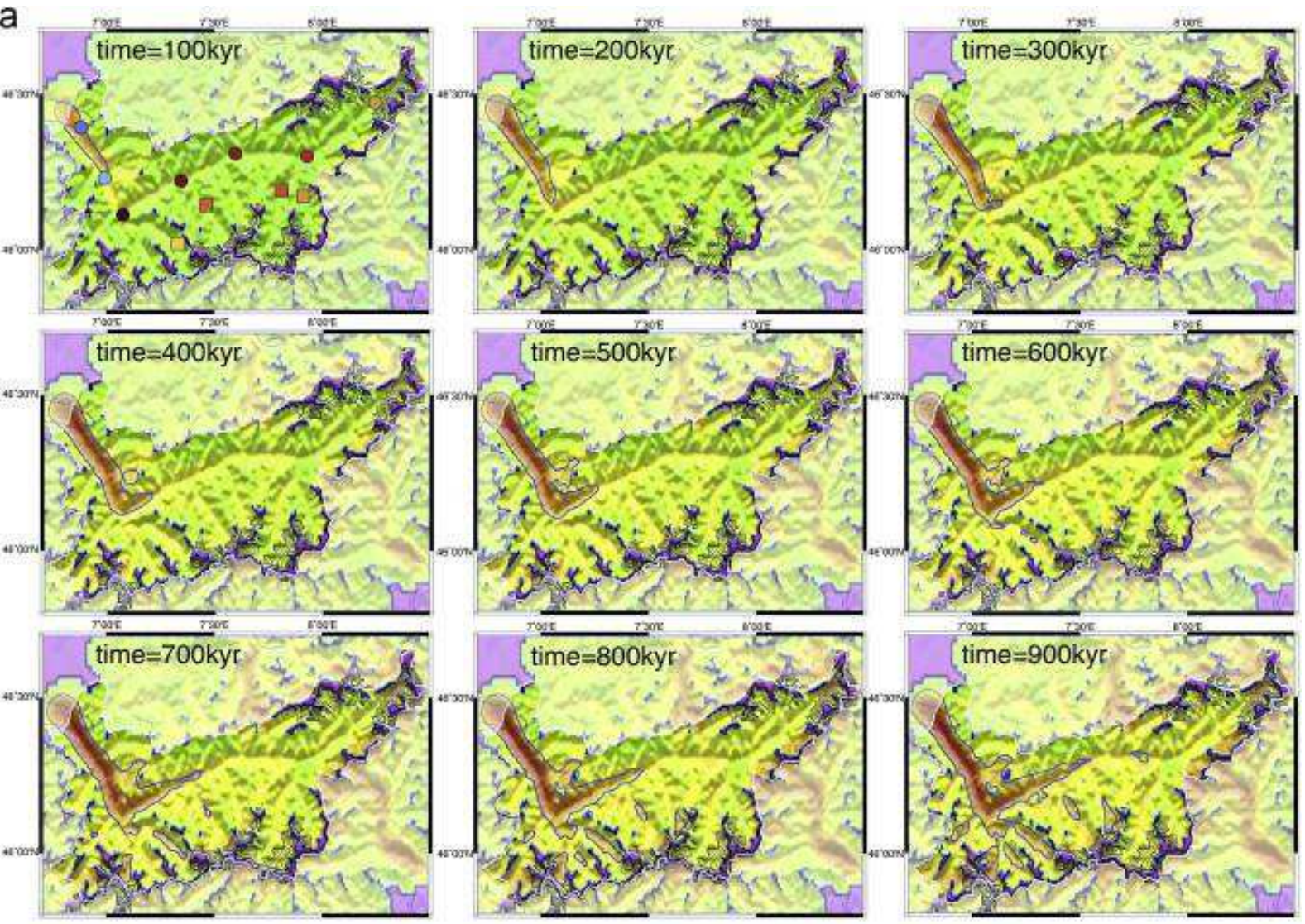

b

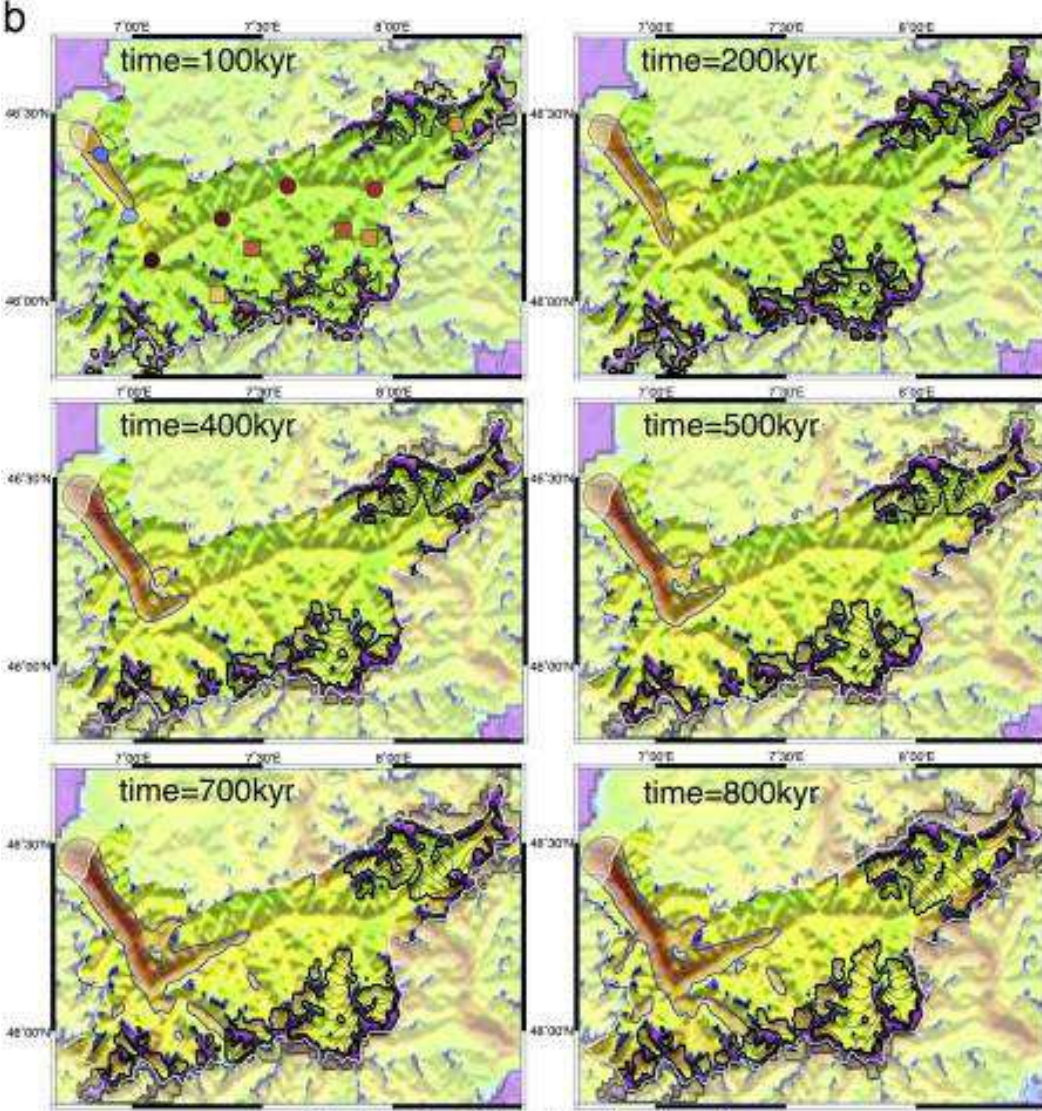

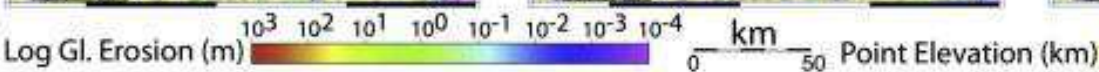

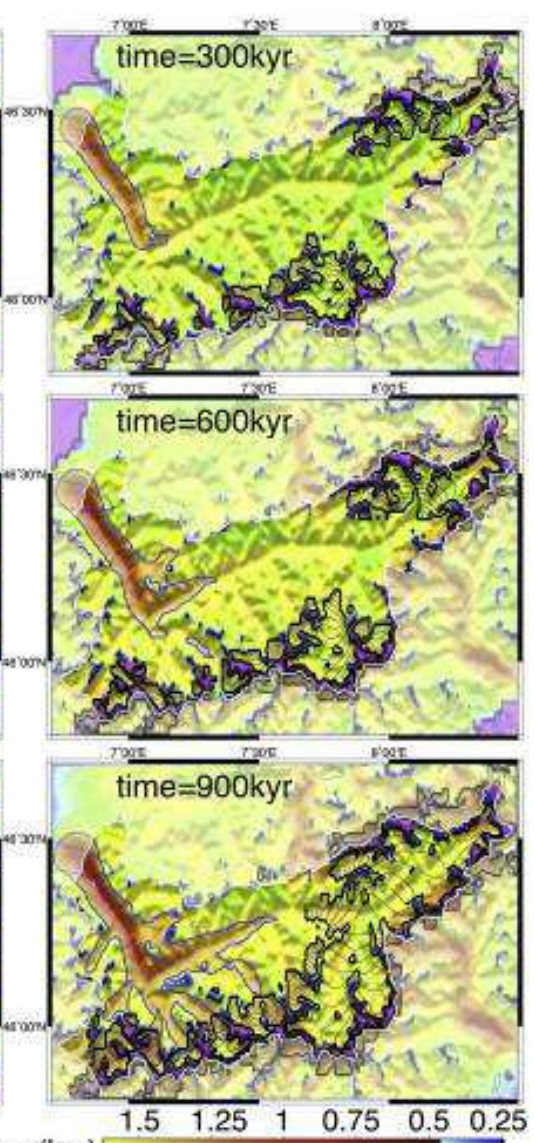


Fig. 6. : Selected, synchronous snapshots from simulations (a) B1 and (b) B2 (see Table 1 and text for details). The blue line in each snapshot represents an isoline of erosion equal to $100 \mathrm{~m}$, highlighting headward propagation of the erosional front throughout glaciation. The location of the control points (color-coded by elevation) is also shown on the top-left snapshots.

\section{a}

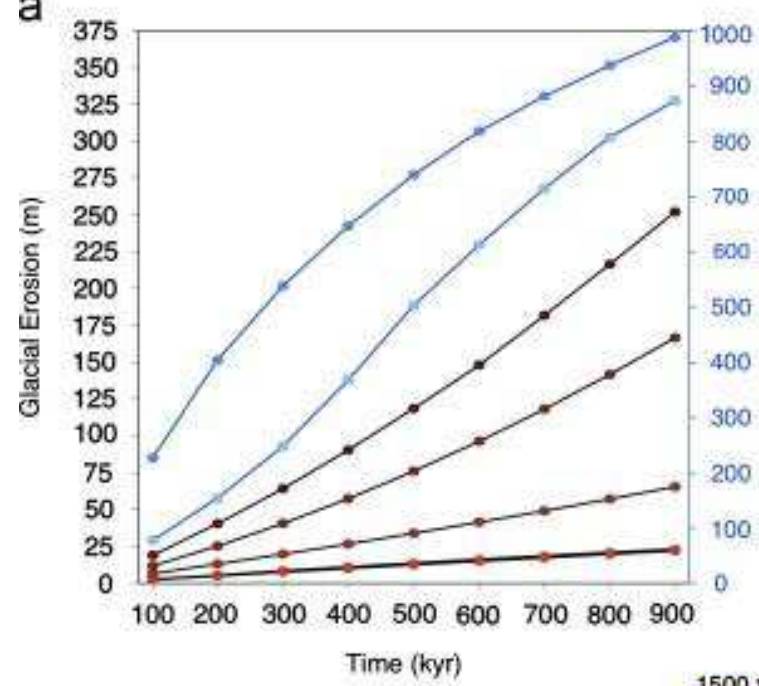

b

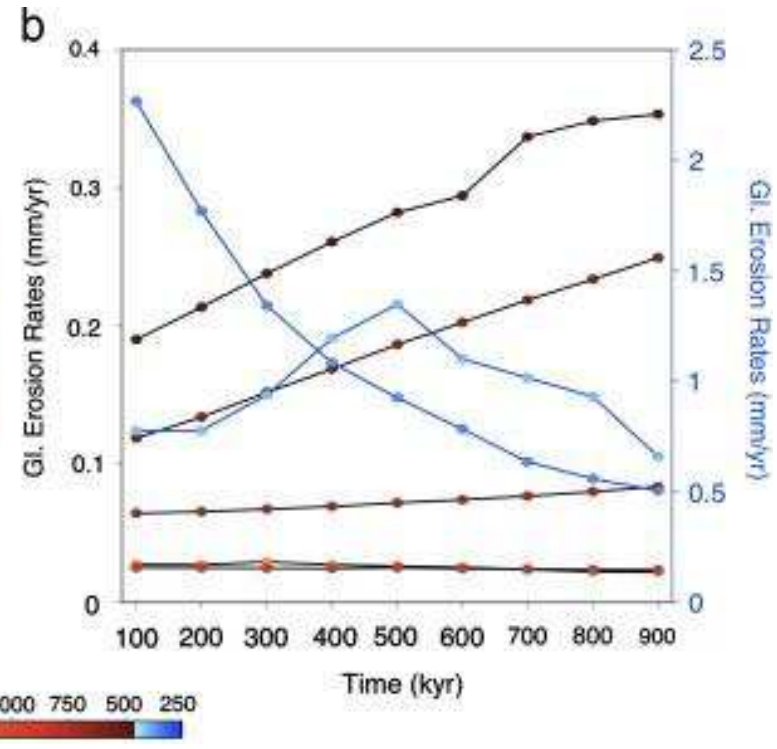

Fig. 7. : Cumulative glacial erosion (a) and instantaneous erosion rates (b) at the end of each glacial/interglacial cycle of simulation B1 (see Table 1), for control points in the main valley trunk (see the top-left snapshots in Fig. 6 for control point locations). Cumulative erosion and instantaneous erosion rates at low elevation (light and dark blue dots on both panels) follows the scale on the right.

Glacial/interglacial oscillations control the ice extent, the velocity pattern and, thus, erosion rates (Fig. 8). A close examination of erosion during a single glacial/interglacial cycle reveals that catchment-integrated sediment production rates are higher during phases of ice advance and retreat, when the glacier is rapidly changing its shape and extent. There is also a decrease of the sediment yield through time, when the simulation does not include any tectonic rock uplift (Fig. 8a). Such a decrease is expected as it is the consequence of a reduction of the glacier's accumulation area. In contrast, we find that a tectonic rock uplift of $0.5 \mathrm{~mm} \mathrm{yr}^{-1}$ compensates for the loss of accumulation area caused by glacial erosion. In fact, the ice volume at the end of each glacial/interglacial cycle increases through time (Fig. 6b) and a constant sediment yield is maintained throughout the entire simulation (Fig. 8b). 

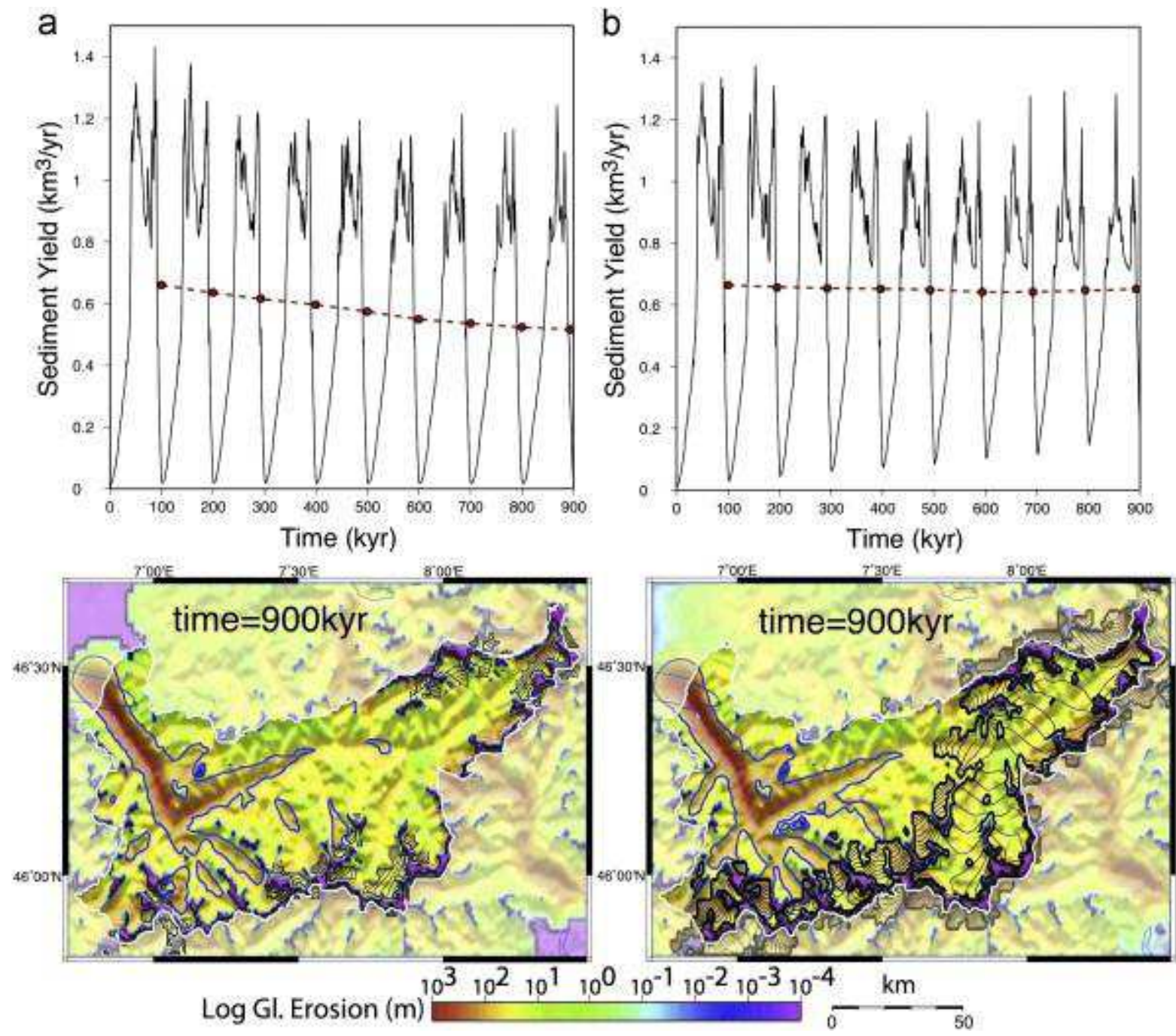

Fig. 8. : (a-b) Temporal evolution of sediment yield (black lines) for simulations B1 and B2, respectively (see Table 1). Sediment yield is maximized during the advancing and retreating phases of the glacier, suggesting that it is independent on the ice volume/extent. The averaged sediment production over each individual glacial/interglacial cycle (red dots and dotted lines) is also shown. The ice extent and cumulative glacial erosion after nine glacial/interglacial cycles (see also Fig. 6) is shown below each panel.

In spite of a number of simplifications that preclude fully reproducing the hypsometric differences between the pre-glacial and present-day topography, the hypsometry of the landscape at the end of this numerical experiment approaches that of the present-day topography (Fig. 2), in turn indicating that the numerical model is able to reproduce first order imprints of glacial erosion.

\subsection{Numerical experiment $C$}

In this numerical experiment, we simulate $2 \mathrm{Myr}$ of glacial erosion on the pre-glacial topography. To mimic the climatic record and reproduce the mid-Pleistocene transition, we impose a shift of the period of climate oscillations from $40 \mathrm{kyr} / \mathrm{symmetric}$ to 
$100 \mathrm{kyr} / \mathrm{asymmetric}$ cycles at $1 \mathrm{Ma}$. We compare the evolution of the ice volume, average ice sliding velocity and glacial sediment yield through time, for different simulations with tectonic rock uplift rates equal to 0 and $0.5 \mathrm{~mm} \mathrm{yr}^{-1}$ (simulations $\mathrm{C} 1$ and $\mathrm{C} 2$, Fig. 9). 

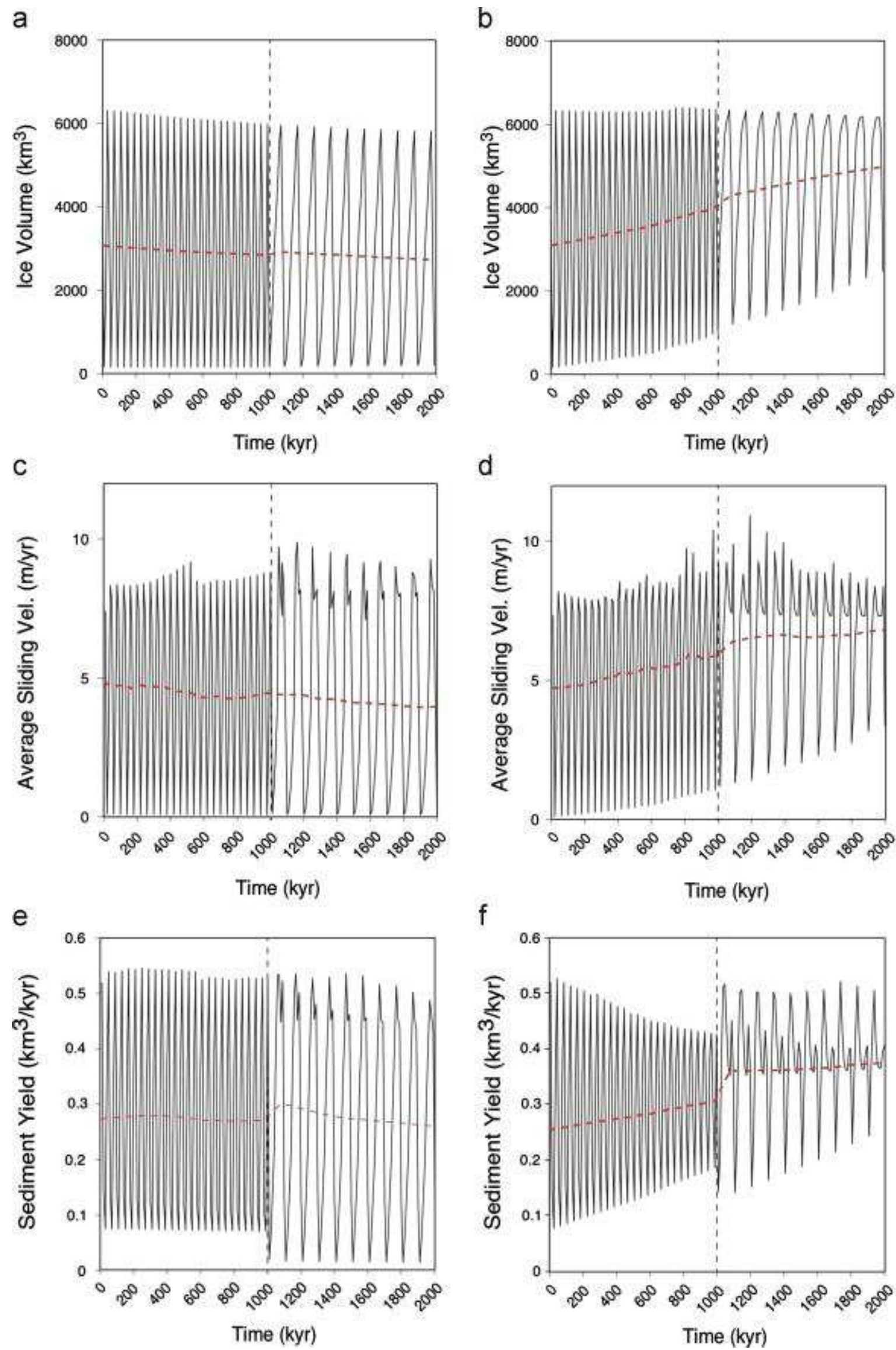
Fig. 9. : Temporal evolution of the ice volume (black lines, a and b), average sliding velocity (black lines, c and d) and sediment yield (black lines, e and f) over 2 Myr glacial modeling. Red, dashed lines represent the results averaged over each glacial/interglacial cycle. Lefthand-side panels show results for the experiment with nil tectonic rock uplift (simulation $\mathrm{C} 1$, see Table 1). Right-hand-side panels show results with $0.5 \mathrm{~mm} \mathrm{yr}^{-1}$ of tectonic rock uplift (simulation C2, see Table 1). After $1 \mathrm{Myr}$, the period of glacial/interglacial cycles shifts from $40 \mathrm{kyr}$ to $100 \mathrm{kyr}$ in both simulations (vertical dashed line).

The major effect of shifting from short/symmetric to long/asymmetric climate oscillations is an increase (up to $15 \%$ ) in ice volume, sliding velocities and sediment yield, especially when a non-isostatic component of rock uplift compensates for the loss of glaciers' accumulation area (Fig. 9). However, this effect is dampened after few long, asymmetric glacial/interglacial cycles, suggesting a rather fast re-equilibration of the erosive regimes to the new climatic conditions. After re-equilibration, variations of ice volume, average sliding velocity and sediment yield are again driven by the tectonic rock uplift (as described in Section 4.2).

\section{Discussion}

Global analyses of topography show that first order variations in mountain height correlates with present-day and LGM ELAs (Broecker and Denton, 1989 and Egholm et al., 2009) and are independent of tectonic forcing (e.g., Champagnac et al., 2012). In fact, the hypsometry of modern glaciated mountain ranges suggests that denudation mechanisms are more effective at high elevations, leading to the conclusion that glacial and periglacial processes may limit mountain elevation (e.g., Mitchell and Montgomery, 2006, Sternai et al., 2011 and Delunel et al., 2010). The present-day landscape, however, is more prone to bear information about the most recent stages of glacial erosion, as erosion itself erases past landforms and, hence, evidence of past erosional processes. Different patterns of glacial erosion on the pre-glacial and present-day topography suggest that glacial effects are not as simple as a "buzzsaw" erosion or increase of topographic relief, but rather that they evolve through time and in relation to the evolution of the landform. Our results show that glacial erosion is focused toward the lower reaches of the landscape during the early stages of glaciation when the landscape still preserves a dominant fluvial morphology (Figs. $4 \mathrm{~g}$ and 5a). Early glacial erosion, thus, produces an increase in topographic relief, consistent with glacial overdeepenings in the modern topography. By dating valley fill deposits within glacial overdeepened troughs in the proximity of the Rhône valley, Preusser et al. (2010) provided a minimum age for the formation of these features $\sim 250 \mathrm{ka}$. Similarly, Häuselmann et al. (2007b) and Valla et al. (2011) found that the major phase of glacial erosion in the Aar and Rhône river basins occurred at $\sim 1$ Ma and increased topographic relief. Our results are in agreement with these findings. During the late stages of glaciation, however, glaciers erode the highest reaches of the landscape (Figs. $4 \mathrm{~h}$ and $5 \mathrm{~b}$ ), a result that matches well with geomorphic investigations of the present-day Alpine topography (Anders et al., 2010 and Sternai et al., 2011).

The erosive power of the glacier is particularly high when it flows down a steeper slope formed during the initial carving of the over-deepened trough. This effect can initiate a headward propagation of glacial erosion (Fig. 6), similar to knickpoints in fluvial domains that migrate from the base-level towards the headwaters (e.g., Seidl and Dietrich, 1992). Headward propagation of glacial erosion was already proposed to explain 
thermochronometric data from the mountainous landscapes of Fiordland, New Zealand, based on thermochronometric data (e.g., Shuster et al., 2011). The headward propagation of glacial erosion matches evidence for a glacially induced increase of topographic relief (Valla et al., 2011) within the Rhône valley as well as increased glacial erosion around the long-term ELA (Sternai et al., 2011) (see also Fig. 2). Our result thus suggests that glacial valley deepening and plane off around the long-term ELA are related processes, linked by headward propagation of glacial erosion through time.

The sediment yield decreases through time in the absence of tectonic rock uplift to compensate for the loss of accumulation area induced by glacial erosion (Fig. 8 and Fig. 9). $0.5 \mathrm{~mm} \mathrm{yr}^{-1}$ of tectonic rock uplift, however, is sufficient to compensate for such a glacially induced loss of accumulation area and produce an increase in sediment production throughout glaciation, in agreement with thermochronometric data (Valla et al., 2011) and measurements of sediment yields from the Alps (Hay et al., 1992 and Kuhlemann et al., 2001). Despite significant advances in measuring and assessing the causes of actual rock uplift in the Alps (Schaer and Jeanrichard, 1974, Kahle et al., 1997, Calais et al., 2002, Lippitsch et al., 2003, Schlatter et al., 2005, Stocchi et al., 2005, Barletta et al., 2006 and Champagnac et al., 2009), the debate about the relative importance of isostatic and tectonic rock uplift on measured values is clearly unresolved. It is therefore difficult to assess whether this theoretical condition depicts the current state of the Alps. It is worth noting, however, that an additional cooling trend superimposed to the glacial/interglacial cycles or an increase of the amplitude of the latter might equally compensate for the loss of accumulation area induced by glacial erosion and, thus, increase the sediment yield. In addition, the lack of fluvial and hillslope processes in our numerical experiments might emphasize this effect. Yet this behavior indicates that, when climate conditions allow glaciation, surface vertical motions and/or longterm climatic trends have a primary control on the production of sediments.

A shift of the period of climate oscillations from $40 \mathrm{kyr} / \mathrm{symmetric}$ to $100 \mathrm{kyr} / \mathrm{asymmetric}$ cycles extends the time spans during which glacial erosion occurs and promotes the production of sediments (Fig. 9). Thus, the mid-Pleistocene transition might have increased the efficiency of glacial erosion. The increase in sediment yield we observe from our models (Fig. 9), however, is too small to explain the roughly twofold increase of valley carving at $\sim 1 \mathrm{Ma}$ (Häuselmann et al., 2007b and Valla et al., 2011) and the sediment budget (Kuhlemann et al., 2001). Additional contributions to glacial valley deepening must therefore be provided by other factors. Pedersen and Egholm (2013) have recently confirmed that cooling at the mid-Pleistocene transition provides an unambiguous mechanism to increase glacial erosion, as already suggested by Muttoni et al. (2003), but ignored the potential effects of rock uplift and its effects on surface elevation (Braun et al., 1998, Tomkin and Braun, 2002, Herman and Braun, 2008 and Yanites and Ehlers, 2012). As we demonstrate here, enhanced rates of rock uplift can also increase glacial erosion by increasing glaciers' accumulation area. Despite little evidence for any significant change of the tectonic rock uplift since the late Pleistocene (Willett, 2010, and references therein) recent detachment of the European slab (Lippitsch et al., 2003) could have provided an additional source of rock-uplift for this region.

\section{Conclusions}

Simulations of glacial erosion on the pre-glacial and present-day landscape calibrated on observational constraints within the Rhône valley enabled us to conclude that: 
The effects of glaciation are more complex than a simple "buzzsaw" effect or increase of topographic relief. Glacial conditioning of a landscape evolves through time and space, in relation with the evolution of the landscape itself. Patterns of glacial erosion on the pre-glacial and present-day topography of the Rhône valley suggest an initial increase of topographic relief followed by enhanced erosion at higher elevations during late stages of glaciation.

Valley (over-)deepening and enhanced glacial erosion around the long-term ELA of the Rhône valley are linked by a headward propagation of glacial erosion through time. Such a headward propagation of glacial erosion is capable of matching evidence of a glacially induced increase of topographic relief within the Rhône valley as well as increased glacial erosion in correspondence of the long-term ELA.

While glacial sediment yields decrease throughout glaciation in the absence of intense fluvial/hillslope erosion, or increase of the amplitude of climate oscillations. A moderate tectonic rock uplift (or cooling trend superimposed to glacial/interglacial cycles), however, is sufficient to increase the production of sediments, in agreement with measurements of sediment yields from the Alps.

Although the change of climate periodicity corresponding to the middle Pleistocene transition may have produced an intensification of glacial erosion, other factors such as an increase of rock uplift and/or progressive climate cooling are required to explain enhanced valley deepening by glacial erosion at $\sim 1 \mathrm{Ma}$.

\section{Acknowledgments}

This work was funded as part of the TOPOAlps project-European Science Foundation. P. Sternai and F. Herman thank the Swiss NSF (Grant 20T021-120499). J.-D. Champagnac thanks the Swiss NSF (Grant PZ00P2-126408). P.G. Valla thanks ETH Zurich for funding. S.D. Willett, F. Schlunegger and two anonymous reviewers provided helpful comments that greatly improved the focus of the paper. R. Reverman helped to improve the text. 


\section{References}

J. Amundson, N.R. Iverson

Testing a glacial erosion rule using hang heights of hanging valleys, Jasper

National Park, Alberta, Canada

J. Geophys. Res., 111 (F01020) (2006)

Anders et al., 2010

A. Anders, S.G. Mitchell, J.H. Tomkin

Cirques, peaks and precipitation patterns in the swiss Alpsconnections among climate, glacial erosion and topography

Geology, 38 (3) (2010), pp. 239-242

Anderson et al., 2006

R. Anderson, P. Molnar, M. Kessler

Features of glacial valley profiles simply explained

J. Geophys. Res., 111 (F01004) (2006) http://dx.doi.org/10.1029/2005JF000344

Barletta et al., 2006

V.R. Barletta, C. Ferrari, G. Diolaiuti, T. Carnielli, R. Sabadini, C. Smiraglia

Glacier shrinkage and modeled uplift of the Alps

Geophys. Res. Lett., 33 (2006) http://dx.doi.org/10.1029/2006GL026490

Benn and Lehmkuhl, 2000

D.I. Benn, F. Lehmkuhl

Mass balance and equilibrium-line altitudes of glaciers in high-mountain environments

Quat. Int., 65/66 (2000), pp. 15-29

Bindschadler, 1983

R. Bindschadler

The importance of pressurized subglacial water in separation and sliding at the glacier bed

J. Glaciol., 29 (1983), pp. 3-19

Bowerman and Clark, 2011

N.D. Bowerman, D.H. Clark

Holocene glaciation of the central Sierra Nevada, California

Quat. Sci. Rev., 30 (9-10) (2011), pp. 1067-1085

Braun et al., 1998

J. Braun, D. Zwartz, J. Tomkin

A new surface-process model combining glacial and fluvial erosion

Ann. Glaciol., 28 (1) (1998), pp. 282-290

Brocklehurst and Whipple, 2002

S. Brocklehurst, K.X. Whipple

Glacial erosion and relief production in the Eastern Sierra Nevada, California

Geomorphology, 42 (1-2) (2002), pp. 1-24

Broecker and Denton, 1989

W.S. Broecker, G.H. Denton 
The role of ocean-atmosphere reorganizations in glacial cycles

Geochim. Cosmochim. Acta, 53 (1989), pp. 2465-2501

Broecker and van Donk, 1970

W.S. Broecker, J. van Donk

Insolation changes, ice volumes and the $\mathrm{O}^{18}$ record in deep sea cores

Rev. Geophys. Space Phys., 8 (1970), pp. 169-198

Brozovic et al., 1997

N. Brozovic, D.W. Burbank, A.J. Meigs

Climatic limits on landscape development in the northwestern Himalayas

Science, 276 (5312) (1997), pp. 571-574

Buoncristiani and Campy, 2004

Buoncristiani, J.F., Campy, M., 2004. In: Ehlers, J., Gibbard, P.L. (Eds.), Quaternary

Glaciations-Extent and Chronology, vol. 2.

Calais et al., 2002

E. Calais, J.-M. Nocquest, F. Jouanne, M. Tardy

Current strain regime in the western Alps from continuous Global Positioning

System measurements, 1996-2001

Geology, 30 (7) (2002), pp. 651-654

Champagnac et al., 2003

J.-D. Champagnac, C. Sue, B. Delacou, M. Burkhard

Brittle orogen-parallel extension in the internal zones of the Swiss Alps (South Valais)

Eclogae Geol. Helv., 96 (2003), pp. 1-14

Champagnac et al., 2007

J.-D. Champagnac, P. Molnar, R.S. Anderson, C. Sue, B. Delacou

Quaternary erosion-induced isostatic rebound in the western Alps

Geology, 35 (3) (2007), pp. 195-198

Champagnac et al., 2009

J.-D. Champagnac, F. Schlunegger, K. Norton, F. von Blanckenburg, L.M. Abbuhl, M.

Schwab

Erosion-driven uplift of the modern Central Alps

Tectonophysics, 474 (2009), pp. 236-249

Champagnac et al., 2012

J.-D. Champagnac, P. Molnar, C. Sue, F. Herman

Tectonic, climate and mountain topography

J. Geophys. Res., 4 (117) (2012), p. B02403

http://dx.doi.org/10.1029/2011JB008348 pp. 424-435

Christensen, 1996

N.I. Christensen

Poisson's ratio and crustal seismology

J. Geophys. Res., 101 (1996), pp. 3139-3156 
Delunel et al., 2010

R. Delunel, P.A. van der Beek, J. Carcaillet, P.G. Valla

Frost-cracking control on catchment denudation ratesinsights from in situ

produced 10Be concentrations in stream sediments (Ecrins-Pelvoux massif, French

Western Alps)

Earth Planet. Sci. Lett., 293 (1-2) (2010), pp. 72-83 (doi:

10.1016/j.eps1.2010.02.020)

Egholm et al., 2009

D.L. Egholm, S.B. Nielsen, V.K. Pedersen, J.-E. Lesemann

Glacial effects limiting mountain height

Nature, 460 (2009), pp. 884-887

Ehlers et al., 2006

T.A. Ehlers, K.A. Farley, M.E. Rusmoren, G.J. Woodsworth

Apatite (U-Th)/He signal of large magnitude and accelerated glacial

erosionsouthwest British Columbia

Geology, 34 (2006), pp. 765-768

Fairbridge, 1972

R.W. Fairbridge

Climatology of a glacial cycle

Quat. Res., 2 (1972), pp. 283-302

Florineth and Schlüchter, 1998

D. Florineth, C. Schlüchter

Reconstructing the Last Glacial Maximum (LGM) ice surface geometry and flowlines in the Central Swiss Alps

Eclogae Geol. Helv., 91 (1998), pp. 391-407

Flowers and Clark, 2002

G. Flowers, G. Clark

A multicomponent coupled model of glacier hydrology1. Theory and synthetic examples

J. Geophys. Res., 107 (2002)

Glotzbach et al., 2011

C. Glotzbach, P.A. van der Beek, C. Spiegel

Episodic exhumation and relief growth in the Mont Blanc massif, Western Alps

from numerical modelling of thermochronology data

Earth Planet. Sci. Lett., 304 (3-4) (2011), pp. 417-430

Hallet, 1979

B. Hallet

A theoretical model of glacial abrasion

J. Glaciol., 17 (1979), pp. 209-222

Hallet, 1996

B. Hallet

Glacial quarryinga simple theoretical model 
Ann. Glaciol., 22 (1-8) (1996)

Harbor et al., 1988

J.M. Harbor, B. Hallet, C.F. Raymond

A numerical model of landform development by glacial erosion

Nature, 333 (1988), pp. 347-349

Häuselmann et al., 2007a

P. Häuselmann, M. Fiebig, P.W. Kubik, H. Adrian

A first attempt to date the original "Deckenshotter" of Penck and Brückner with cosmogenic nuclides

Quat. Int., 164-165 (2007), pp. 33-42

Häuselmann et al., 2007b

P. Häuselmann, D.E. Granger, P.Y. Jeannin, S.E. Lauritzen

Abrupt glacial valley incision at 0.8 ma dated from cave deposits in Switzerland

Geology, 35 (2) (2007), pp. 143-146

Hay et al., 2002

W. Hay, E. Soeding, R. Deconto, C. Wold

The Late Cenozoic uplift climate change paradox

Int. J. Earth Sci., 91 (2002), pp. 746-774

Hay et al., 1992

W.W. Hay, C.N. Wold, J.M. Herzog

Preliminary mass balanced 3-D reconstructions of the Alps and surrounding areas during the Miocene

R. Pflug, J.W. Harbaugh (Eds.), Computer Graphics in Geology. Lecture Notes in Earth Science, vol. 41 (1992), pp. 99-110

Herman et al., 2011

F. Herman, F. Beaud, J.-D. Champagnac, J.-M. Lemieux, P. Sternai

Glacial hydrology and erosion patternsa mechanism for carving glacial valleys

Earth Planet. Sci. Lett., 310 (2011), pp. 498-508

Herman and Braun, 2008

F. Herman, J. Braun

Evolution of the glacial landscape of the Southern Alps of New Zealandinsight from a glacial erosion model

J. Geophys. Res., 113 (F02009) (2008) http://dx.doi.org/10.1029/2007JF000807

IUGG/UNEP/UNESCOIUGG/UNEP/UNESCO, 2005

IUGG/UNEP/UNESCO, 2005. Fluctuations of Glaciers 1995-2000. Technical Report, World Glacier Monitoring Service, Zurich, Switzerland.

Ivy-Ochs et al., 2006

S. Ivy-Ochs, H. Kerschner, A. Reuther, M. Maisch, R. Sailer, J. Schaefer, P.W. Kubik, H.-A. Synal, C. Schluchter

The timing of glaciers advances in the northern European Alps based on surface exposure dating with cosmogenic ${ }^{10} \mathrm{Be},{ }^{26} \mathrm{Al},{ }^{36} \mathrm{Cl}$ and ${ }^{21} \mathrm{Ne}$

Geol. Soc. Am. Bull., 415 (2006), pp. 43-60 
Jaboyedoff and Derron, 2005

M. Jaboyedoff, M.-H. Derron

A new method to estimate the infilling of alluvial sediment of glacial valleys using a sloping local base level

Geogr. Fis. Dinam. Quat., 28 (2005), pp. 37-46

Kahle et al., 1997

Kahle, H.-G., Marti, U., Geiger, A., Wirth, B., Guble, E., 1997. Recent crustal movements, geoid and density determination: contribution from integrated satellite and terrestrial measurements. In: Pfiffner, O. (Ed), Deep Structure of the Swiss Alps: Results of NRP20, pp. 251-259.

Kaplan et al., 2009

M.R. Kaplan, A.S. Hein, A. Hubbard, S.M. Lax

Can glacial erosion limit the extent of glaciation?

Geomorphology, 103 (2) (2009), pp. 172-179

Kelly et al., 2004

M.A. Kelly, J.-F. Buoncristiani, C. Schluchter

A reconstruction of the last glacial maximum (LGM) ice-surface geometry in the western Swiss Alps and contiguous Alpine regions in Italy and France

Eclogae Geol. Helv., 97 (2004), pp. 57-75

Kessler et al., 2008

M. Kessler, R. Anderson, J. Briner

Fjord insertion into continental margins driven by topographic steering of ice

Nat. Geosci., 1 (2008), pp. 365-369

Koppes and Montgomery, 2009

M.N. Koppes, D.R. Montgomery

The relative efficacy of fluvial and glacial erosion over modern to orogenic timescales

Nat. Geosci., 2 (9) (2009), pp. 644-647

Kuhlemann, 2000

J. Kuhlemann

Post-collisional sediment budget of circum-Alpine basins (Central Europe)

Mem. Ist. Geol. Mineral. Univ. Padova, 52 (2000), pp. 1-91

Kuhlemann et al., 2001

J. Kuhlemann, W. Frisch, I. Dunkl, B. Szekely

Quantifying tectonic versus erosive denudation by the sediment budgetthe

Miocene core complexes of the Alps

Tectonophysics, 55 (2001), pp. 1-23

Lippitsch et al., 2003

R. Lippitsch, E. Kissling, J. Ansorge

Upper mantle structure beneath the Alpine orogen from high-resolution teleseismic tomography

J. Geophys. Res., 108 (2003) http://dx.doi.org/10.1029/2002JB002016 
Lisiecki and Raymo, 2007

L.E. Lisiecki, M.E. Raymo

Plio-Pleistocene climate evolutiontrends and transitions in glacial cycle dynamics

Quat. Sci. Rev., 26 (1-2) (2007), pp. 56-69

MacGregor et al., 2000

K.C. MacGregor, R.S. Anderson, S.P. Anderson, E.D. Waddington

Numerical simulations of glacial-valley longitudinal profile evolution

Geology, 28 (2000), pp. 1031-1034

Mancktelow, 1985

N. Mancktelow

The Simplon linea major displacement zone in the western Lepontine Alps

Eclogae Geol. Helv., 78 (1) (1985), pp. 73-96

Maurer et al., 1997

H.R. Maurer, N. Burkhard, N. Deichmann, A.G. Green

Active tectonics in the central Alpscontrasting stress regimes north and south of the Rhone Valley

Terra Nova, 9 (2) (1997), pp. 91-94

Mitchell and Montgomery, 2006

S.G. Mitchell, D.R. Montgomery

Influence of a glacial buzzsaw on the height and morphology of the Cascade

Range in central Washington State, USA

Quat. Res., 65 (2006), pp. 96-107

Mitrovica and Peltier, 1991

J.X. Mitrovica, W.R. Peltier

A complete formalism for the inversion of post-glacial rebound dataresolving power analysis

Geophys. J. Int., 104 (2) (1991), pp. 267-288

Molnar, 2004

P. Molnar

Late Cenozoic increase in accumulation rates of terrestrial sedimenthow might climate change have affected erosion rates?

Annu. Rev. Earth Planet. Sci., 32 (2004), pp. 67-89

Molnar and England, 1990

P. Molnar, P. England

Late Cenozoic uplift of mountain ranges and global climate changechicken or egg?

Nature, 346 (1990), pp. 29-34

Montgomery, 2002

D.R. Montgomery

Valley formation by fluvial and glacial erosion

Geology, 30 (11) (2002), pp. 1047-1050

Muttoni et al., 2003 
G. Muttoni, C. Carcano, E. Garzanti, M. Ghielmi, A. Piccin, R. Pini, S. Rogledi, D. Sciunnach Onset of major Pleistocene glaciations in the Alps

Geol. Soc. Am. Bull., 31 (11) (2003), pp. 989-992

Norton et al., 2010

K.P. Norton, L.M. Abbuhl, F. Schlunegger

Glacial conditioning as an erosional driving force in the Central Alps

Geology, 38 (2010), pp. 655-658

Oerlemans, 1984

J. Oerlemans

Numerical experiments on glacial erosion

Z. Gletscherkd. Glazialgeol., 20 (1984), pp. 107-126

Paterson, 1994

W. Paterson

The Physics of Glaciers

Pergamon (1994)

Pedersen and Egholm, 2013

Pedersen, V.K., Egholm, D.L., 2013. Glaciations in response to climate variations preconditioned by evolving topography. Nature 493, 206-210.

Pelletier et al., 2010

J. Pelletier, D. Comeau, J. Kargel

Controls of glacial valley spacing on Earth and Mars

Geomorphology, 116 (2010), pp. 189-201

Pelletier, 2004

J.D. Pelletier

Estimate of three-dimensional flexural-isostatic response to unloadingrock uplift due to late Cenozoic glacial erosion in the western United States

Geology, 32 (2) (2004), pp. 161-164

Penck, 1905

A. Penck

Glacial features in the surface of the Alps

J. Geol., 13 (1) (1905), pp. 1-19

Penck and Brückner, 1909

Penck, A., Brückner, E., 1909. Die Alpen im Eiszeitalter. Tauchnitz. Leipzig.

Philippe et al., 2012

Philippe Steer, Ritske S. Huismans, Pierre G. Valla, Sébastien Gac \& Frédéric Herman

Nature Geoscience 5, 635-639 10.1038/ngeo1549.

Piper et al., 1994

D.J.W. Piper, P.J. Mudie, A.E. Aksu, K.I. Skene

A 1 Ma record of sediment flux south of the grand banks used to infer the development of glaciation in southeastern Canada

Quat. Sci. Rev., 13 (1) (1994), pp. 23-37 
Preusser et al., 2010

F. Preusser, J. Reitner, C. Schlüchter

Distribution, geometry, age and origin of overdeepened valleys and basins in the Alps and their foreland

Swiss J. Geosci., 103 (2010), pp. 407-426

Reynolds and Smith, 1995

R.W. Reynolds, T.M. Smith

A high-resolution global sea surface temperature climatology

J. Climate, 8 (1995), pp. 1571-1583

Roe et al., 2008

G. Roe, K.X. Whipple, J.K. Fletcher

Feedbacks among climate, erosion, and tectonics in a critical wedge orogen

Am. J. Sci., 308 (2008), pp. 815-842

Schaer and Jeanrichard, 1974

J.P. Schaer, F. Jeanrichard

Mouvements verticaux anciens et actuels dans les Alpes suisses

Eclogae Geol. Helv., 67 (1974), pp. 101-119

Schlatter et al., 2005

A. Schlatter, A. Schneider, A. Geiger, H.-G. Kahle

Recent vertical movements from precise levelling in the vicinity of the city of

Basel, Switzerland

Int. J. Earth Sci., 94 (4) (2005), pp. 507-514

Schlüchter et al., 2009

Schlüchter, C., Bini, A., Buoncristiani, J.F., Couterrand, S., Ellwanger, D., Felber, M., Florineth, D., Graf, H.R., Keller, O., Kelly, M.A., Schoeneich, P., 2009. Switzerland during last glacial maximum (1:50,000). Federal Office of Topography swisstopo.

Schmid et al., 2004

S.M. Schmid, B. Fugenschuh, E. Kissling, R. Schuster

Tectonic map and overall architecture of the Alpine orogen

Eclogae Geol. Helv., 97 (2004), pp. 93-117

Schmidt and Montgomery, 1996

K.M. Schmidt, D.R. Montgomery

Rock mass strength assessment for bedrock land sliding

Environ. Eng. Geosci., 2 (1996), pp. 325-338

Seidl and Dietrich, 1992

Seidl, M.A., Dietrich, W.E., 1992. The problem of channel erosion into bedrock. In:

Schmidt, K.-H., de Ploey, J. (Eds.), Functional Geomorphology. Geomorphology, Catena

Supplement. Verlag, Cremlingen-Destedt, pp. 101-124.

Selverstone, 2005

J. Selverstone

Are the Alps collapsing? 
Annu. Rev. Earth Planet. Sci., 33 (2005), pp. 113-132

Shuster et al., 2011

D.L. Shuster, K.M. Cuffey, J.W. Sanders, G. Balco

Thermochronometry reveals headward propagation of erosion in an Alpine landscape

Science, 332 (2011), pp. 84-88

Shuster et al., 2005

D.L. Shuster, T.A. Ehlers, M.E. Rusmoren, K.A. Farley

Rapid glacial erosion at $1.8 \mathrm{Ma}$ revealed by ${ }^{4} \mathrm{He} /{ }^{3} \mathrm{He}$ thermochronometry

Science, 310 (5754) (2005), pp. 1668-1670

Spotila et al., 2004

J.A. Spotila, J.T. Buscher, A.J. Meigs, P.W. Reiners

Long-term glacial erosion of active mountain beltsexample of the Chugach-Stdot Elias Range, Alaska

Geology, 32 (6) (2004), pp. 501-504

Steck and Hunziker, 1994

Steck, A., Hunziker, J., 1994. The Tertiary structural and thermal evolution of the central Alps-compressional and extensional structures in an orogenic belt. Tectonophysics 238, 229-254.

Steer et-al., 2012

Steer, P., Huismans, R.S., Valla, P.G., Gac, S., Herman, F., 2012. Bimodal Plio-Quaternary glacial erosion of fjords and low-relief surfaces in Scandinavia. Nat. Geosci. 5, 635-639, 10.1038/ngeo1549.

Sternai et al., 2012

P. Sternai, F. Herman, J.-D. Champagnac J.-D., Fox M.R., B. Salcher, S.D. Willett

Pre-glacial topography of the European Alps

Geology, 40 (2012), pp. 1067-1070 10.1130/G33540.1

Sternai et al., 2011

Sternai, P., Herman, F., Fox, M.R., Castélltort, S., 2011. Hypsometric analysis to identify spatially variable glacial erosion. J. Geophys. Res. 116, F03001, 10.1029/2010JF001823.

Stewart and Watts, 1997

J. Stewart, A.B. Watts

Gravity anomalies and spatial variation of flexural rigidity at mountain ranges

J. Geophys. Res., 102 (1997), pp. 5327-5352

Stocchi et al., 2005

P. Stocchi, G. Spada, S. Cianetti

Isostatic rebound following the Alpine deglaciationimpact on the sea level variations and vertical movements in the Mediterranean region

Geophys. J. Int., 162 (1) (2005), pp. 137-147

Sue et al., 1999

C. Sue, F. Thouvenot, J. Frchet, P. Tricart 
Widespread extension in the core of the western Alps revealed by earthquake analysis

J. Geophys. Res., 104 (1999), pp. 25611-25622

Sue et al., 2007

Sue, C., Delacou, B., Champagnac, J.-D., Allanic, C., Tricart, P., Burkhard, M., 2007.

Extensional neotectonics around the bend of the western/central Alps: an overview. Int.

J. Earth Sci 96,1101-1129 10.1007/s00531-007-0181-3

Sugden and John, 1976

D.E. Sugden, B.S. John

Glaciers and LandscapeA Geomorphological Approach

Edward Arnold, London (1976)

Tomkin and Braun, 2002

J.H. Tomkin, J. Braun

The influence of alpine glaciation on the relief of tectonically active mountain belts

Am. J. Sci., 302 (2002), pp. 169-190

Valla et al., 2011

P.G. Valla, D.L. Shuster, P.A. van der Beek

Significant increase in relief of the European Alps during mid-Pleistocene glaciations

Nat. Geosci., 4 (688-692) (2011) http://dx.doi.org/10.1038/NGEO1242

Valla et al., 2010

P.G. Valla, P.A. van der Beek, D. Lague

Fluvial incision into bedrockinsights from morphometric analysis and numerical modeling of gorges incising glacial hanging valleys (Western Alps, France)

J. Geophys. Res., 115 (2010)

van der Veen, 1987

van der Veen, C., 1987. Longitudinal stresses and basal sliding: a comparative study. In: Dynamics of the West Antarctic Ice Sheet: Proceedings of a Workshop held in Utrecht, May 6-8, 1985. D. Reidel Pub. Co.

Vernon et al., 2008

A.J. Vernon, P.A. van der Beek, H.D. Sinclair, M.K. Rahn

Increase in late neogene denudation of the European Alps confirmed by analysis of a fission track thermochronology database

Earth Planet. Sci. Lett., 270 (3-4) (2008), pp. 316-329

Ward et al., 2012

D.J. Ward, R.S. Anderson, P.J. Haeussler

Scaling the Teflon peaksgranite, glaciers, and the highest relief in North America

J. Geophys. Res., 117 (2012)

Willenbring and von Blanckenburg, 2010

J.K. Willenbring, F. von Blanckenburg 
Long-term stability of global erosion rates and weathering during late-Cenozoic cooling

Nature, 465 (2010), pp. 211-214

Willett, 2010

S.D. Willett

Late Neogene erosion of the Alpsa climate driver?

Annu. Rev. Earth Planet. Sci., 38 (2010), pp. 411-437

Yanites and Ehlers, 2012

B.J. Yanites, T.A. Ehlers

Global climate and tectonic controls on the denudation of glaciated mountains

Earth Planet. Sci. Lett., 325-326 (2012), pp. 63-75

Zachos et al., 2001

J. Zachos, M. Pagani, L. Sloan, E. Thomas, K. Billpus

Trends, rhythms and aberrations in global climate $65 \mathrm{Ma}$ to present

Science, 292 (2001), pp. 686-693

Zhang et al., 2001

P. Zhang, P. Molnar, W.R. Downs

Increased sedimentation rates and grain sizes 2-4 Myr ago due to the influence of climate change on erosion rates

Nature, 401 (2001), pp. 891-897 